\title{
Guided osteotomy and implants placed with free hands for double full arch rehabilitation with immediate prosthetic loading
}

\author{
Osteotomia guiada e implantes instalados com as mãos livres \\ para reabilitação de arco duplo total com \\ carga protética imediata
}

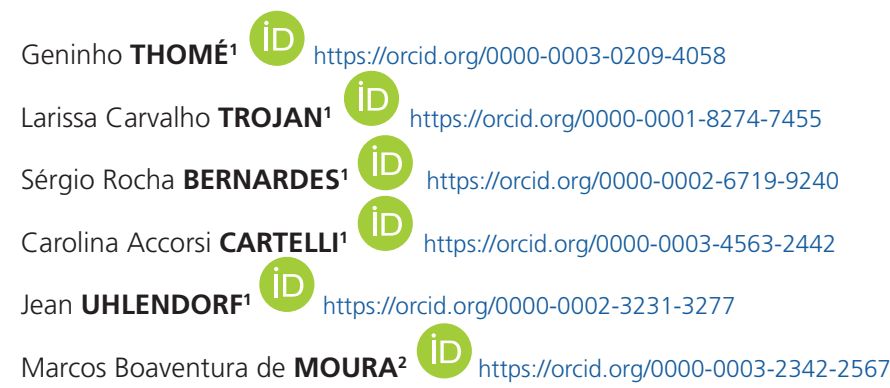

\section{ABSTRACT}

Precise planning for dental implant placement requires appreciation of anatomical limitations and restorative purpose. Diagnosis can be made by complementary exams such as panoramic radiography and cone-beam computed tomography. The purpose of this study was to rehabilitate the upper and lower jaw of a patient with severe periodontal disease using a guided osteotomy and implants placed with free hands and Morse taper implants. The concept of guided surgery was used to prepare the alveolar bone to place eight implants, four implants in the upper jaw and four implants in the lower jaw, all have achieved a minimum torque of $60 \mathrm{Ncm}$. The modified suture technique was used to better stabilize the soft tissue around the mini conical abutments. The analogues were scanned by CAD/CAM for confection of the metallic structures of the bridges. On the third day, the upper and lower full arch prostheses were installed and simultaneous bilateral contacts were adjusted. After 12 months of patient follow-up, the implants and prostheses were in good condition of aesthetics and function, maintaining the success of the rehabilitation. Within the limitations of this clinical case, it can be concluded that the implants placed with free hands was facilitated by a previous guided osteotomy.

Indexing terms: Dental implantation. Dental prosthesis. General surgery.

$\boldsymbol{\nabla} \boldsymbol{\nabla} \boldsymbol{\nabla}$

1 Faculdade ILAPEO, Departamento de Implantodontia. Curitiba, PR, Brasil.

2 Universidade Federal de Uberlândia, Departamento de Oclusão, Prótese Fixa e Materiais Dentários. Av. Pará, 1720, 38405-902, Uberlândia, MG, Brasil. Correspondence to: MB MOURA. E-mail: <boaventura.mm@hotmail.com>.

$\boldsymbol{\nabla} \boldsymbol{\nabla} \boldsymbol{\nabla}$

How to cite this article

Thomé G, Trojan LC, Bernardes SR, Cartelli CA, Uhlendorf J, Moura MB. Guided osteotomy and implants placed with free hands for double full arch rehabilitation with immediate prosthetic loading. RGO, Rev Gaúch Odontol. 2020;68: e20200025. http://dx.doi.org/10.1590/1981863720200002520180029 


\section{RESUMO}

O planejamento preciso para a instalação de implantes dentários requer a apreciação das limitações anatômicas e objetivos restaurativos. O diagnóstico pode ser feito por exames complementares, como radiografia panorâmica e tomografia computadorizada de feixe cônico. O objetivo deste estudo foi reabilitar, a mandíbula superior e inferior de um paciente com doença periodontal severa, utilizando uma osteotomia guiada e implantes cone Morse instalados com as mãos livres. O conceito de cirurgia guiada foi utilizado para preparar o osso alveolar para a instalação de oito implantes, quatro implantes no maxilar superior e quatro implantes no maxilar inferior, todos alcançando um torque mínimo de $60 \mathrm{Ncm}$. A técnica de sutura modificada foi utilizada para melhor estabilizar o tecido mole ao redor dos mini-pilares cônicos. Os abutments foram escaneados por CAD/CAM para confecção das estruturas metálicas das próteses dentárias. No terceiro dia, as próteses de arco superior e inferior foram instaladas e os contatos bilaterais simultâneos foram ajustados. Após 12 meses de acompanhamento do paciente, os implantes e próteses estavam em boas condições de estética e função, mantendo o sucesso da reabilitação. Dentro das limitações deste caso clínico, pode-se concluir que os implantes instalados com as mãos livres foram facilitados pelo uso prévio da osteotomia guiada.

Termos de indexação: Implantação dentária. Prótese dentária. Cirurgia geral.

\section{INTRODUCTION}

Edentulous patients have been benefited from the use of full implant-supported by dentures, which promotes greatly improvement of chewing, phonetic and aesthetic capacity $[1,2]$. The survival and success rates of full-arch dental prostheses are high, independent of the loading protocol followed (conventional, delay and immediate) [3-5]. Immediate loading is characterized by the installation of the total prosthesis (full arch) within 7 days, provided the implants have a minimum torque of $30 \mathrm{Ncm}$ [6].

The high level of stress in the bone/implant/ prosthesis system can result in screws loosening, bone loss and even prothesis failure [4]. Passive fit between the metal structure of the prostheses and the implants is important for maintaining the rehabilitation long-term success [6-8]. This clinical aspect is obtained when the structure is in contact simultaneously with all abutments, without bending or tensile forces $[7,8]$. Due to mechanical problems related to the bone/implant/prosthesis system, new implant designs and prosthetics interfaces have been studied and developed [9].

Some studies suggest mechanical advantages in the stability of Morse type connections compared to hexagonal connections $[9,10]$. Considering the Morse connection, the prosthetic abutment is attached to the implant by the screw and the friction, resulting in a mechanical (frictional) locking between the implant cone and the abutment cone. This locking type allows prosthetic abutment to reduce the preload loss and possibility of micro-movement during masticatory loads, without overloading the fixation screw and reducing the incidence of loosening or fracture [10], which usually happens in hexagonal connections [11].
The well-known full arch treatment technique has been used for protocols of immediate function. This technique involves the placement of implants for the rehabilitation of fully edentulous dental arches and with diminished bone volume when just four implants are planned. The implants should be well anchored, up to 45 degrees (achieving a primary stability of at least $30 \mathrm{Ncm}$ ). The success rate for this technique has been described with a high success rate (98\% for the maxilla and $98.1 \%$ for the mandible after 5 to 10 years of follow-up) [12].

The concept of software planning and guided surgeries combined with immediate loading was clinically introduced to almost 2 decades [13]. Initial treatments evolved to guided computer-assisted implant surgery. The use of surgical planning software with DICOM files from computed tomography (CT) or cone-beam computed tomography $(\mathrm{CBCT})$ can be converted into three-dimensional (3D) images, which will allow precise and virtual planning of the exact position and direction of implants. The precision of the virtual prosthesis depends on a surgical model and a fixed acrylic prosthesis [13-15].

The objective of this study was demonstrating a new approach for a double arch prosthetic/functional rehabilitation of a severe periodontally patient using a guided osteotomy and hybrid conical dental implants placed with free hands.

\section{CASE REPORT}

A 38-year-old man presented at the Department of Dentistry, with chief complain of generalized tooth mobility. The patient has presented in this report as smoker. At the first moment, anamnesis and radiographic 
examination were performed. At the time of the clinical and radiographic examination was noted the presence of chronic periodontal disease with points of exacerbation, generalized bone loss and mobility grade 3 in several teeth (figure 1).

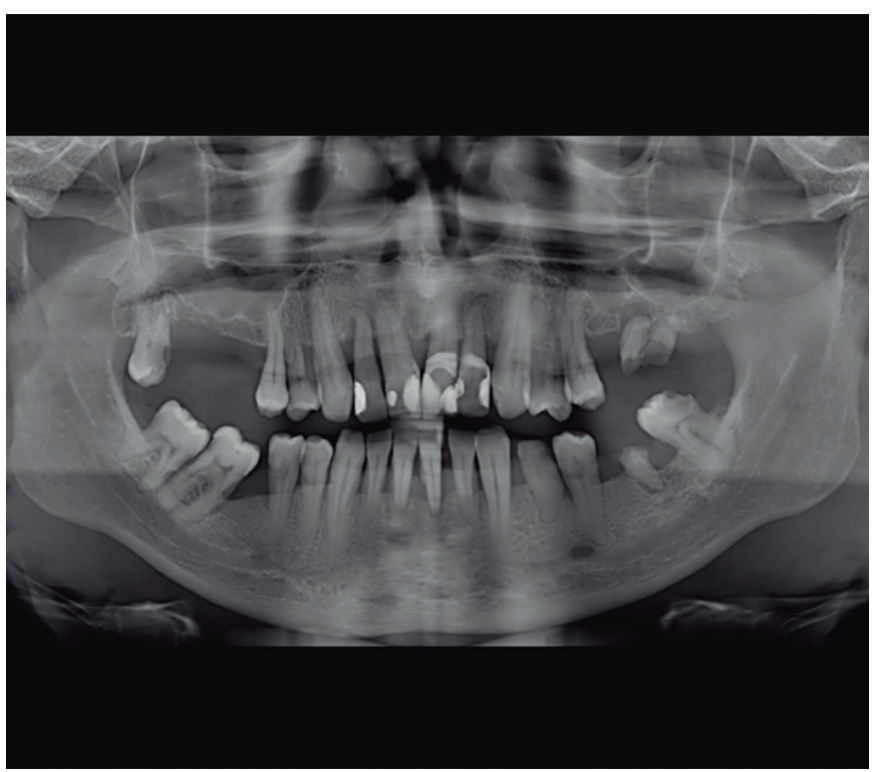

Figure 1. Initial panoramic X-Ray.

It was suggested the extraction of all dental elements to place dental implants and install two full arch prostheses with immediate loading. After clinical examination and careful radiographic and CBCT images analysis of the patient oral and dental conditions. The patient was asked for serum exams which showed good general health conditions for performing the surgical procedure.

Initially, the patient impression has been taken, the vertical dimension of occlusion (OVD) was recorded, duplication of the waxing to make the multifunctional guide. Intra-oral scanning of the upper and lower arches of the patient was performed to make the dent-supported surgical guides, using an intraoral scanner (Trios, 3Shape, Copenhagen, Denmark). Scanning the patient's mouth allows us to plan, together with CBCT the ideal positioning of the implants using the software. It was planned full extraction and immediate placement of 8 implants, 4 implants were placed in each dental arch and the full arch prostheses.
As it will be necessary some osteotomy to regularize the alveolar bone, it was suggested a guided osteotomy and implants placed with free hands. This technique is based on guided drill sequence, aiming to achieve the best 3D implant position and followed by conventional implant placement without a guide placing the implants with "free hands". In the software, selective extraction was performed, and it was decided to maintain the upper and lower canines and molars. In this way, the superior surgical guide was made to support the teeth \#13,\#18, \#23 and \#27; and, the inferior arch, in the teeth \#33, \#37, \#43, \#47 and \#48. (figures 2 and 3).

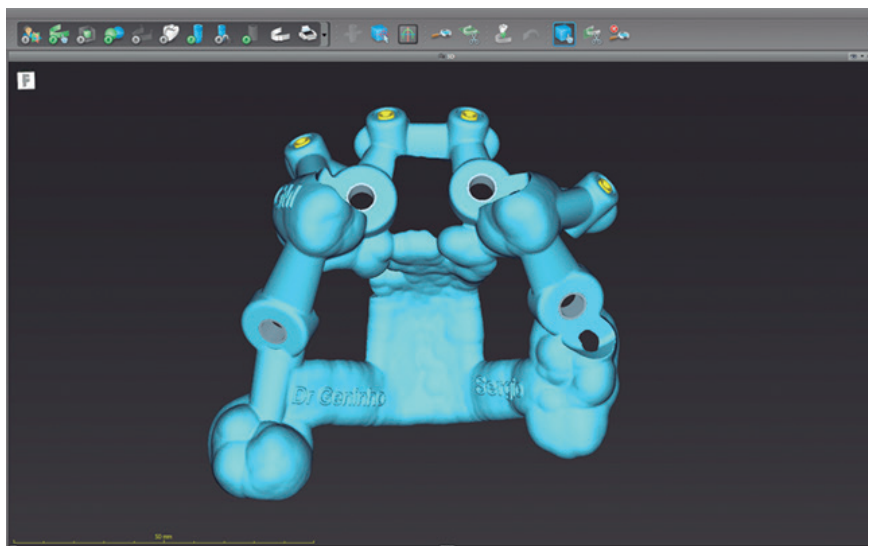

Figure 2. Surgical guide upper

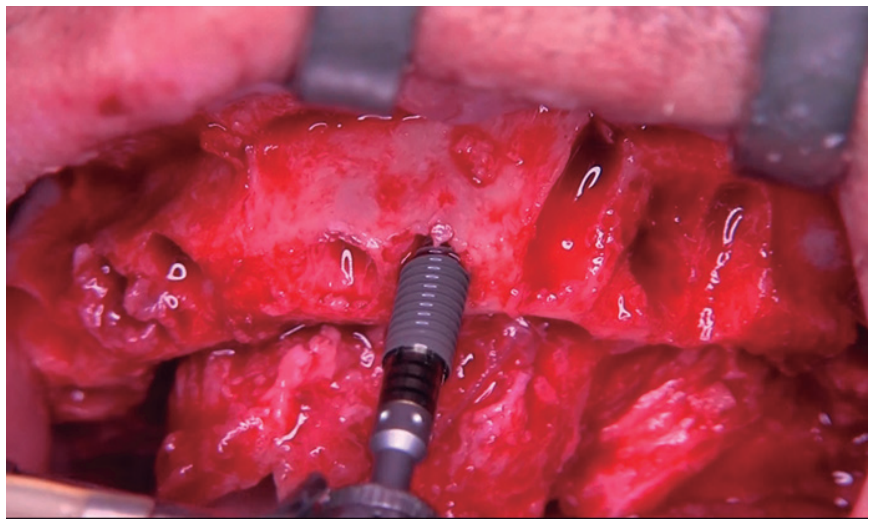

Figure 3. Placement of implant in the upper arch.

\section{Description of the implants and abutments used}

It was placed eigth Helix Grand Morse implants (Neodent, Curitiba, Brazil), which present some important 
characteristics: 1. Hybrid conical implants with compacting threads in the coronal area and cutting threads in the medial and apical third; 2. Double threads for minimal trauma and faster placement; 3. Conical apex with lowactivity channels and helical flutes designed to optimize primary stability. Regarding the abutments, it was installed Grand Morse mini conical angled abutment of 17 and 30 degrees (Neodent) which has an anatomical design to improved soft tissue accommodation.

\section{Surgical Procedures}

After local anesthesia of the regions of the maxilla, partial extraction was done (\#11, \#12, \#14, \#15, \#21, $\# 22$, \#24 and \#25) aiming to fit the surgical drill guide on the remaining teeth $(\# 13, \# 18, \# 23$ and $\# 27$ ). The drill sequence was performed following the manufacturer instruction in the regions of the teeth \#12,\#14, \#22 and \#24. The support teeth were extracted and a supra crestal, oblique incisions were done, followed by flap detachment from to the second molar, bilaterally. The alveolar bone was regularized with and surgical milling cutter. After that, the length of all perforations was checked to properly choose the implants. Four conical implants were placed (Helix GM Aqua implants $4.0 \times 13 \mathrm{~mm}$; Neodent), all with minimum torque of $60 \mathrm{Ncm}$. Four mini conical abutments (Neodent) with $2.5 \mathrm{~mm}$ of transmucosal height were installed, two was 17 degrees angled (anterior implants) and the two 30 degrees angled (posterior implants). The continuous suture was also performed with nylon 5.0.

Lower arch surgery followed the same sequence. After the local anesthesia, multiple teeth extractions were performed (\#31, \#32, \#34, \#35, \#36, \#41, \#42, \#44 and \#45). The surgical guide was positioned on five remaining teeth (\#33, \#37, \#43, \#47 and \#48) for drilling with a drill of $2.0 \mathrm{~mm}$ in the regions of the teeth \#31, \#34, \#41 and \#44. As the bone density was similar to bone type $1 / 1 \mathrm{l}$, the drill sequence was followed by conical drill $3.5 \mathrm{~mm}$, $3.75 \mathrm{~mm}$ and conical contour 3.75 drill. The surgical guide was removed, and the supporting teeth was extracted. Supracrestal and oblique incision and detachment of the flap was perfomed, and after alveolar bone regularization, the proper implant length was checked. Four implants Helix GM Aqua 3.75 x $13 \mathrm{~mm}$ (Neodent) were placed $2 \mathrm{~mm}$ subcrestal, all with minimum torque of $60 \mathrm{Ncm}$. Four mini conical abutments (Neodent) were installed at $2.5 \mathrm{~mm}$ transmucosal height (Straight abutment for the anterior implants and 17 degrees angled in the posterior implants).

A modified suture technique was performed on the lower arch to keep the soft tissue more stable around the mini conical abutment. For this purpose, a perforation was performed in the lingual surface of alveolar bone between the implants using a straight handpiece drill 1.1 with a 45 degrees inclination bone platform. Thus, a hole was created for the passage of the suture needle. The suture was performed with nylon 5.0, initiated by the buccal soft tissue, followed by entry into the channel created (towards the lingual ridge) and was closed through the lingual soft tissue (figure 4).

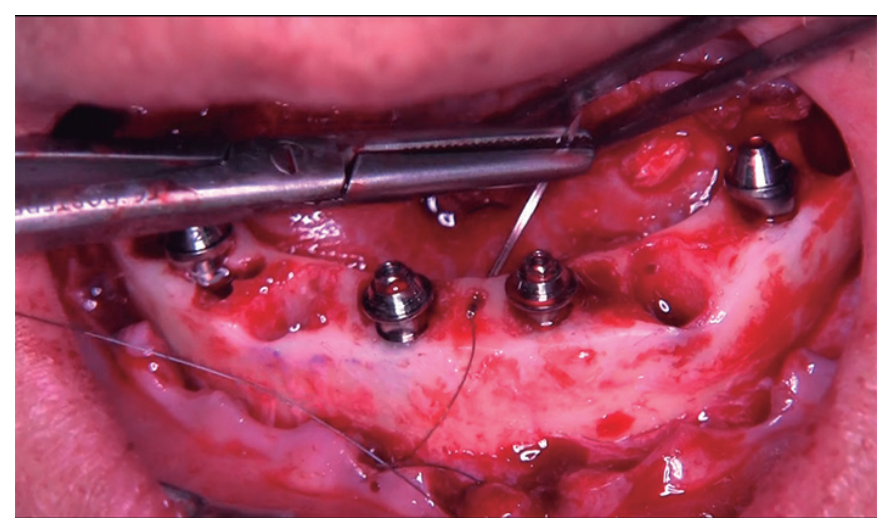

Figure 4. Step-by-step image of the modified suture. The suture needle passes through the buccal soft tissue and through the lingual bone perforation.

After suture, impression copings were positioned in the mini conical abutments and attached to the multifunctional guide by acrylic Pattern Resin (GC America Inc, Alsip, USA). With the upper and lower guides in position, a 3-point occlusal registration was performed considering the vertical dimension previously determined. The impression was done with condensation silicone Speedex (Coltene, Altstätten, Switzerland). The impression copings were unscrewed, the impression was removed and sent to the laboratory for manufacture the metal bars and the teeth assembly.

After the teeth assembly was proved and the occlusion checked, the model was double scanned (3Shape, Copenhagen, Denmark) (1-model with the assembly teeth in wax; 2-model with scanbody) (Neodent) in the miniconical abutment analogs. This image was exported to a CAD software were the full arch bars were designed and then milled in titanium bars (DMG HSC 20 
linear, München, Germany). The bars were then sent to the laboratory for teeth assembly in wax.

After esthetical and functional try in approved, the full arch prostheses were acrylated and installed on the third postoperative day. The occlusal adjustment was performed maintaining bilateral stability at maximum intercuspation, contacts and occlusal forces equally distributed, anterior guide and smooth lateral mandibular excursions without work-side and non-working interferences (figure 5).

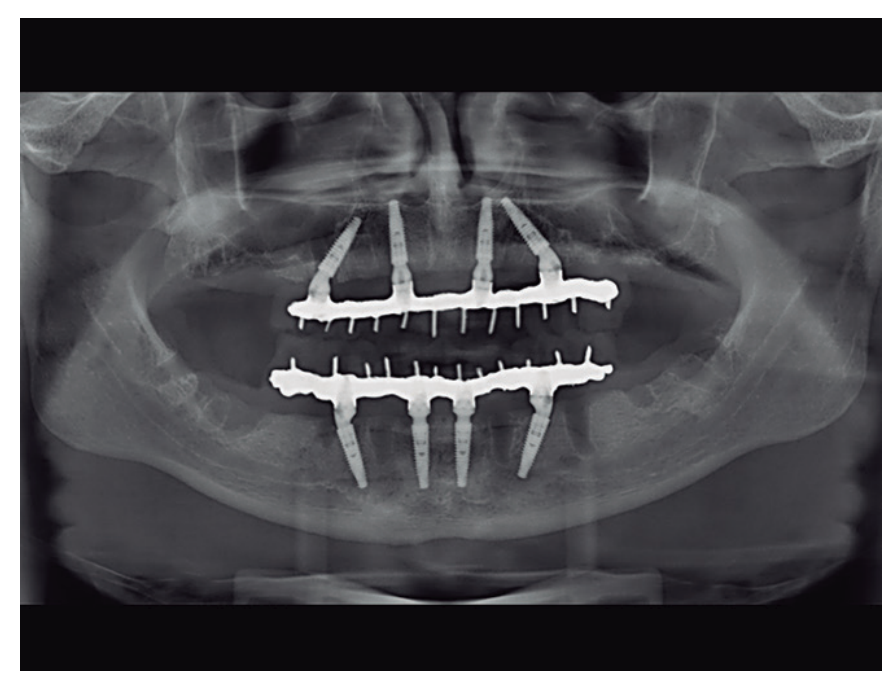

Figure 5. Panoramic radiograph 24 hours after surgery, showing implant placement and passive adaptation of protocols and mini-abutments.

The suture was removed 15 days after surgery and oral hygiene orientation was performed. The clinical and radiographic control was done after 1, 2, 3, and 4, 8 and 12 months (figure 6). The patient signed the informed consent form performing all the procedures.

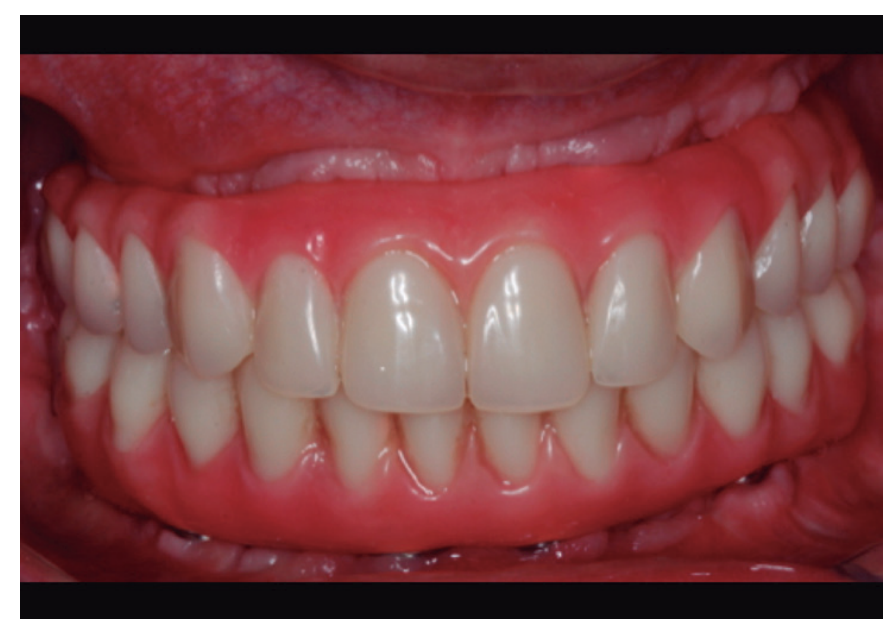

Figure 6. Follow-up of 12 months of prostheses installation.

\section{DISCUSSION}

Dental extractions have been motivated by several causes, including cavity with extensive damage, unsuccessful or repeated endodontic treatments, fractures and advanced periodontal disease. The replacement of missing teeth has been largely accomplished through the placement of osseointegrated implants, described in the 1960s by Branemark [16], who recommended twostage techniques and healing periods of 3 to 6 months. A significant number of researches have focused on providing patients with safe, simple and rapid treatment - the singlestage surgical procedure - retaining the excellent results of previous methods [17].

Some factors could cause changes in the bone/ implant/prosthesis system. The length of the cantilever present in the superstructure increases the stress values around periimplant area, which can be an important factor, causing severe bone resorption [18]. Some other mechanical factors can also cause stress around implants, such as high muscle strength, poor bone quality, bruxism and lateral occlusion applied to the supra-structure with cantilevers [18].

The placement of dental implants in patients with periodontal disease history did not show statistical differences in survival rates when compared to individuals without periodontal disease, suggesting the procedure appeared to be viable and safe. The implant score or length, type and extent of the prosthesis also did not differ statistically [19].

The presence of a marginal space between the implant and the abutment may lead to greater marginal bone loss due to the penetration of bacteria at the implant-abutment interface [10]. The conical implantabutment systems have delayed or even prevented bacterial colonization through the use of the platform switching concept, resulting in improved implant system performance $[10,20]$. Another important point is the precision of the adjustment or passive adaptation, and several factors can influence the final adaptation: the structure of the wax pattern, the casting process, the production of the final prosthesis and the delivery of the same [21]. Over the years complications associated with misfit in the prosthesis-implant or implant-abutment structure have been reported, such as: mechanical failures, pillar rotation, loosening or fracture of prosthetic screws, 
poor distribution of forces and biological failure, such as adverse tissue reactions, sensitivity and pain [22].

The success of the immediate loading can be partially attributed to the splinting effect provided by a full bar, joining all the implants, the rigorous oral hygiene regime and the standardization of surgical and prosthetic procedures [23]. The short-term success of immediate loading in mandibular protocols was comparable to that of late loading protocols [24]. Papaspyridakos et al. suggested the immediate loading is an excellent alternative to overcome the problems of conventional loading [3]. The present study demonstrated excellent stability of implants with immediate loading after 12 months, without any failure and complications.

Much scientific and mediatic emphasis has been given to the use of guided surgery for dental implants placement, which guarantees predictability and a lower degree of morbidity. Some dynamic navigation systems have been used for implant placement, presented similar precision to static guides generated by CBCT. However, the accuracy of guided surgery is significantly improved when compared to the conventional (free hand) implant placement [25]. Surgical guidance for implant placement relieves the clinician of multiple operative decisions. The CAD/CAM system has also been used and has facilitated the position implant [26]. Surgical and prosthetic full arch rehabilitation supported by four implants and guided surgery is viable, with a high success rate and survival results of dental implants [27].

The techniques available until now for maxillomandibular complex rehabilitation are effective, presenting high success rates [28]. Two hundred ninety individuals were submitted to the placement of 1429 implants and prosthesis type protocol, the prosthesis survival rate was $98.6 \%$, the implants $99.6 \%$ and the prosthesis success rate was $96.6 \%$, follow-up was 4.4 years [28]. The treatment time should be taken into account, especially in patients with an oral condition that is directly affecting their quality of life or in elderly patients. The technique proposed in this case may exemplify an alternative to patient rehabilitation with less morbidity.

\section{CONCLUSION}

In conclusion, the technique described with guided osteotomy and implants placed with free hands allowed a double full arch rehabilitation in a single surgical stage, in a faster and less invasive procedure. The modified suture technique provided the quickest stabilization and tissue healing around the abutments. After 12 months of follow-up, the implants and prostheses were in good condition, maintaining healthy of soft tissue and bone around the implant platform. More studies are needed with a greater number of patients and longer time of proservation.

\section{Collaborators}

G THOMÉ, performed the patient's surgery on the case report, and participated in the final approval of the work. SR BERNARDES and CA CARTELLI, performed the prosthetic part and follow-up of the patient, contributed with the conception of the work; acquisition and analysis of data, preparation of the work. LC TROJAN, J UHLENDORF and MB MOURA contributed to the design of the work; revising and final approval of the work.

\section{REFERENCES}

1. Drago C, Gurney L. Maintenance of implant hybrid prostheses: clinical and laboratory procedures. J Prosthodont. 2013;22(1):28-35. https://doi.org/10.1111/J.1532-849X.2012. 00899.x

2. Vieira RA, Melo AC, Budel LA, Gama JC, de Mattias Sartori IA, Thomé $G$. Benefits of rehabilitation with implants in masticatory function: is patient perception of change in accordance with the real improvement? J Oral Implantol. 2014;40(3):263-269. https://doi.org/ 10.1563/AAID-JOI-D-11-00208

3. Papaspyridakos P, Chen CJ, Chuang SK, Weber HP. Implant loading protocols for edentulous patients with fixed prostheses: a systematic review and meta-analysis. Int J Oral Maxillofac Implants. 2014;29 (Suppl):256-270. https://doi. org/10.11607/jomi.2014suppl.g4.3

4. Romanos GE, Gupta B, Eckert SE. Distal cantilevers and implant dentistry. Int J Oral Maxillofac Implants. 2012;27(5):1131-1136.

5. Thomé $E$, Lee $H J$, Sartori $I A$, Trevisan RL, Luiz J, Tiossi R. A randomized controlled trial comparing interim acrylic prostheses with and without cast metal base for immediate loading of dental implants in the edentulous mandible. Clin Oral Implants Res. 2015;26(12):1414-1420. https://doi.org/10. $1111 / \mathrm{clr} .12470$

6. Watanabe F, Uno I, Hata Y, Neuendorff G, Kirsch A. Analysis of stress distribution in a screw-retained implant prosthesis. Int J Oral Maxillofac Implants. 2000;15(2):209-218.

7. Sahin S, Cehreli MC. The significance of passive framework fit in implant prosthodontics: current status. Implant Dent. 2001;10(2):85-92

8. Karl M, Winter W, Taylor TD, Heckmann SM. In vitro study on passive fit in implant-supported 5-unit fixed partial dentures. Int J Oral Maxillofac Implants. 2004;19(1):30-37. 
9. Schmitt CM, Nogueira-Filho G, Tenenbaum HC, Lai JY, Brito $\mathrm{C}$, Döring $\mathrm{H}$, et al. Performance of conical abutment (Morse Taper) connection implants: a systematic review. J Biomed Mater Res A. 2014;102(2):552-574. https://doi.org/10.1002/ jbm.a.34709

10. Merz BR, Hunenbart S, Belser UC. Mechanics of the implantabutment connection: an 8-degree taper compared to a butt joint connection. Int J Oral Maxillofac Implants. 2000;15(4):519-526.

11. de Moura MB, Rodrigues RB, Pinto LM, de Araújo CA, Novais VR, Júnior PCS. Influence of Screw Surface Treatment on Retention of Implant-Supported Fixed Partial Dentures. J Oral Implantol. 2017;43(4):254-260. https://doi.org/10.1563/ aaid-joi-D-16-00145

12. Malo P, de Araújo Nobre M, Lopes A, Francischone C, Rigolizzo M. "All-on-4" immediate-function concept for completely edentulous maxillae: a clinical report on the medium (3 years) and long-term (5 years) outcomes. Clin Implant Dent Relat Res. 2012;14(Suppl 1):e139-150. https://doi.org/10.1111/ j.1708-8208.2011.00395.x

13. Lopes A, Maló P, de Araújo Nobre M, Sánchez-Fernández $E$, Gravito I. The NobelGuide® All-on-4® Treatment Concept for Rehabilitation of Edentulous Jaws: A Retrospective Reporto $\mathrm{n}$ the 7-Years Clinical and 5-Years Radiographic Outcomes. Clin Implant Dent Relat Res. 2017;19(2):233-244. https://doi. org/10.1111/cid.12456

14. Colombo M, Mangano C, Mijiritsky E, Krebs M, Hauschild $U$, Fortin T. Clinical applications and effectiveness of guided implant surgery: a critical review based on randomized controlled trials. BMC Oral Health. 2017;17(1):1-9. https:// doi.org/10.1186/s12903-017-0441-y

15. Vercruyssen M, Hultin M, Van Assche N, Svensson K, Naert I, Quirynen M. Guided surgery: accuracy and efficacy. Periodontol 2000. 2014(1);66:228-246. https://doi.org/10.11 11/prd. 12046

16. Brånemark $\mathrm{Pl}$, Adell $\mathrm{R}$, Breine $\mathrm{U}$, Hansson $\mathrm{BO}$, Lindström J, Ohlsson A. Intra-osseous anchorage of dental prostheses. I. Experimental studies. Scand J Plast Reconstr Surg. 1969;3(2):81-100.

17. Cooper LF, Rahman A, Moriarty J, Chaffee N, Sacco D. Immediate mandibular rehabilitation with endosseous implants: simultaneous extraction, implant placement, and loading. Int J Oral Maxillofac Implants. 2002;17(2)517-525.

18. Gonda T, Yasuda D, Ykebe K, Maeda Y. Biomechanical factors associated with mandibular cantilevers: analysis with threedimensional finite element models. Int J Oral Maxillofac Implants. 2014;29(6):275-282. https://doi.org/10.11607/jomi. 3663
19. Correia F, Gouveia S, Felino AC, Costa AL, Almeida RF. Survival Rate of Dental Implants in Patients with History of Periodontal Disease: A Retrospective Cohort Study. Int J Oral Maxillofac Implants. 2017;32(4):927-934. https://doi.org/10.11607/jomi. 3732

20. Tesmer M, Wallet S, Koutouzis T, Lundgren T. Bacterial colonization of the dental implant fixture-abutment interface: an in vitro study. J Periodontol. 2009;80(12):1991-1997. https://doi.org/10.1902/jop.2009.090178

21. Abduo J, Judge RB. Implications of implant framework misfit: a systematic review of biomechanical sequelae. Int J Oral Maxillofac Implants. 2014;29(3):608-621. https://doi. org/10.11607/jomi.3418

22. Kano SC, Binon PP, Curtis DA. A classification system to mensure the implant-abutment microgap. Int J Oral Maxillofac Implants. 2007;22(6):879-885

23. Chiapasco M. Early and immediate restoration and loading of implants in completely edentulous patients. Int J Oral Maxillofac Implants. 2004;19(Suppl):76-91.

24. Alsabeeha N, Atieh M, Payne AG. Loading protocols for mandibular implant overdentures: a systematic review with meta-analysis. Clin Implant Dent Relat Res. 2010;12 Suppl 1:e28-38. https://doi.org/10.1111/j.1708-8208.2009.00152.x

25. Block MS, Emery RW, Cullum DR, Sheikh A. Implant Placement Is More Accurate Using Dynamic Navigation. J Oral Maxillofac Surg. 2017;75(7):1377-1386. https://doi.org/10.1016/j.joms. 2017. 02.026

26. Sarment DP, Sukovic P, Clinthorne N. Accuracy of implant placement with a stereolithographic surgical guide. Int J Oral Maxillofac Implants. 2003;18(4):571-577.

27. Lopes A, Maló $P$, de Araújo Nobre M, Sánchez-Fernández $E$, Gravito I. The NobelGuide $®$ All-on-4® Treatment Concept for Rehabilitation of Edentulous Jaws: A Retrospective Report on the 7-Years Clinical and 5-Years Radiographic Outcomes. Clin Implant Dent and Relat Res. 2017;19(2):233-244. https://doi. org/10.1111/cid.12456

28. Able FB, de Mattias Sartori IA, Thomé G, Moreira Melo AC. Retrospective, cross-sectional study on immediately loaded implant-supported mandibular fixed completearch prostheses fabricated with the passive fit cementation technique. J Prosthet Dent. 2018;119(1):60-66. https://doi. org/10.1016/j.prosdent.2017.02.006

Received on: 1/11/2018 Final version resubmitted on: 2/4/2019 Approved on: 29/4/2019 